\title{
THE OCCURRENCE OF CODE-SWITCHING AND CODE-MIXING IN THE NOVEL ME AND YOU VERSUS THE WORLD
}

\author{
Gemi Nastiti Lestari, Endang Susilawati, Luwandi Suhartono \\ Program Studi Pendidikan Bahasa Inggris FKIP Untan Pontianak \\ Email: gemi.nastiti@student.untan.ac.id
}

Submitted: 18 June 2021

doi: $10.26418 /$ jeep.v3i1.47423
Accepted: 25 august 2021

Online Published: 23 February 2021

URL: http:/ / dx.doi.org/10.26418/jeep.v3i1.47423

\begin{abstract}
The objective of this research is to know the most occurrence types of code used in the novel and the purposes that contribute to those occurrences. The data were derived from qualitative technique using a novel as the material. The data were analyzed using manual coding and descriptive qualitative. The result of this research showed that code-switching is the most code used rather than code-mixing. The total of the utterances that used code-switching is 53 in total. Meanwhile, the most type of code-switching that used in the novel is intra-sentential which has 27 in total. There were some purposes that contributed to those occurrences, namely, quoting somebody else, express solidarity, and express disapproval. In the novel, switching a code is used to quote a famous expression, proverb, or writing some well-known figures. Also, it is used to express solidarity, to show the bonding between characters. A status relationship between people may be relevant in choosing the appropriate code. Additionally, express disapproval also can contribute to the occurrence in the novel, to express anger or unpleasant events. Therefore, the three factors are contributed to the occurrence of code-switching in the novel.
\end{abstract}

Keywords: Descriptive, Coding, Code-Switching, Code-Mixing, Factors

\section{To cite this paper (in APA style):}

Lestari, G. N., Susilawati, E., Suhartono, L. (2022). The occurrences of code-switching and code-mixing in the novel Me and You Versus the World. Journal of English Education Program, 3(1), 1-6.

\section{INTRODUCTION}

People who speak two or additional languages are referred to as bilingual or multilingual. Many of us during this world will speak not solely in 2 languages in daily life. Indonesian speak a minimum of 2 languages, particularly Indonesian national language or Bahasa and their regional languages. People that square measure knowing or people that have an interest in alternative languages usually master a distant language, like English, Mandarin, Korean, Japanese, etc. 
The very fact that folks will use quite one language encourages them to combine and to piece of cloth language whenever they speak. No surprise folks will use quite one language at the same time. Wardaugh \& Fuller (2015) believes once 2 or additional folks communicate with one another, the system they use is named a code. The condition wherever folks use code within the same topic and context or someone in communication is named code-switching and code-mixing.

Code-Switching and Code-Mixing may be seen in written and auditory communication. Code shift and code mixture in auditory communication may be detected in a very huge screen film, radio, television show, teaching-learning method, conversations between 2 or additional folks, and additionally drama series. Whereas in communication, it may be seen in magazines, newspapers, novels, etc. During this analysis, the researcher would like to investigate an Indonesian novel entitled $\mathrm{Me}$ and You Versus the World that uses code-switching and code-mixing throughout the novel. The researcher has gained little information by asking around students who already had an experience in listening subject of English Education Study program academic year 2019/2020 and found signs of anxiety among the students. The students who have listening comprehension skill has more self-confidence that makes them able to reach high score achievement. They are already familiar with the oral communication produced in the listening material because they have some learning strategies in the past and now that makes them have no worries in learning foreign language.

The researcher selected the novel Me and You Versus the World, published in 2012, written by Stanley Meulen and has been promoted to the big screen in 2014. This novel could be a teenaged and romantic genre novel. There square measure 2 previous analysis that became the benchmark of this research, the primary one is Code Switching in Critical Eleven by Adi (2018). The aim of this analysis is to seek out the categories of code switching used in the novel and to explain the explanations influencing the employment of code switching within the novel. Adi used descriptive qualitative analysis to investigate information by describing and explaining the information that has been obtained. The researcher gained the information through reading the complete contain of the novel. The results of the analysis reveal that largely inter-sentential switching of auditory communication employed in this novel.

The second is code-switching and code-mixing that square measure employed in a classroom, between students and teacher in teaching learning process. The titled is Code Switching and Code mixing in Teaching Learning Process by Ningsih (2019). The main target of this analysis is to understand what the dominant use of code-switching and code-mixing within the teaching learning process. In general, this analysis has similar topic with those 2 previous researches. The previous analysis targeted on communication and writing. However, the second previous analysis additional targeted on auditory communication and academic. According to Adi (2018), code-switching could be a development that is proscribed to monolingual things. It will solely be found within the bilingual or multilingual community. 
There square measure three styles of code-switching. They are inter-sentential, intra-sentential, and tag-switching. Meanwhile, Musyken (2000) uses the term 'code-mixing' to refer 'all cases wherever lexical things and grammatical options from two languages seem in one sentence. There square measure three styles of code-mixing according to Muysken (2000). They are insertion, alternation, and congruent lexicalization.

Code-switching and code-mixing square measure widespread phenomena in bilingual communities. The reason that has been explained, the scientist finished that code-switching is a vigorous method in bilinguals, however not essentially dynamical either language. It is created up as they speak. Significantly, each speaker should be bilingual or have some basic data for this to create sense. Meanwhile, code mixing is additionally closely associated with code-switching. It is associate activity wherever the folks within the society combine their language with alternative languages by borrowing or exploitation some words of foreign language and still influenced by maternal language. For instance, word 'gratis' in Bahasa is that the original language from Dutch that mean 'free' in English. In short, the variations between code-switching and code-mixing are measure seen by the definition and that means. Meanwhile, the activity is closely connected. Code-switching and code-mixing aren't occurred by the accident, there square measure some social factors why folks use this code. According to Holmes (2013), there square measure four factors that triggered folks to use code. They are quoting somebody else, express solidarity, switching for effective function, to soften or strengthen request or command.

\section{RESEARCH METHOD}

In this research, the researcher used descriptive qualitative research to gather and analyze the information that carries with it all statements or utterances containing code-switching and code-mixing within the Indonesian novel by Stanley Maineulen entitled Me and You Versus the World. Ary et al. (2010) state that qualitative researchers look for to grasp a development by specializing in the whole image instead of breaking it down into variables. The aim is to dig deeper into what is not concerning variety. The researcher collected the qualitative data. The researcher used a document in the form of a novel book. Content analysis is used as the technique of data collection. Bowen (2009) states, content analysis is that the method of organising data into classes associated with the central queries of the analysis. Prasad (2008) adscititious the material for the content analysis may be letters, diaries, newspaper content, folk songs, short stories, massages of radio, television, documents, texts or any symbols. The researcher used an Indonesian novel as the material to gather the information. The information was collected by reading an entire novel, highlighting, classifying, and categories.

According to Ary et al. (2010), there are three steps to analyze the qualitative data.

1. The first one is familiarizing. As an example, browse the complete story, re-reading, and creating the research worker conversant in it.

2. The second is coding. The process by which the researcher classified each sentence or utterances to find the type used and the dominant type used.

The last one is representing the data. During this stage, the researcher explained and showed it in the descriptive form 


\section{RESULT AND DISCUSSION}

The result shows the whole of each code. It shows the foremost code that employed in the novel is code-switching with fifty-three utterances in total. Meanwhile, intra-sentential is that the most sort employed in the novel. There area unit many functions that contributed to those occurrences. They are quoting somebody else, express solidarity, and express disapproval. Based on the finding, it is proven that the dominant code found within the novel Me and You Versus the World is code-switching. Meanwhile, the dominant type found within the novel is intra-sentential. Also, the purpose of using code-switching and code-mixing in the novel Me and You Versus the World, namely, quoting somebody else, and express disapproval.

According to the total that has been counted, code-switching is that the most code employed in the novel. It may be seen that code-switching and code-mixing area unit similar however not identical. The method of code-mixing is formed as one thing equivalent to borrowing (Muysken, 2000). It means that code-mixing and borrowing a word from another language is essentially similar. As people know that borrowing is the process of adapted a language for use in another language.

This is slightly totally different from code-switching. Code-switching is that the wide accepted term for the linguistic development whereby a speaker uses 2 linguistic codes among one speech event, alternating between phrases, clauses, and utterances, often with no change in addressee or subject (Toribio, 2011). Also, code-switching is a phenomenon which is limited to bilingual or multilingual situations (Adi, 2018). It is spontaneously exchange by multilingual people and multilingual people. In the same way, code-switching and code-mixing are used by bilingual. Monolingual cannot communicate as well as bilingual people. In the novel, the author describes the environment and lifestyle of the characters who live in urban areas, namely Jakarta. Starting from Jeremy, the main character and also the first-person point of view, Jeremy tells of himself who works in an advertising office which has many customers from various countries. It makes Jeremy living in a high-class society. In the same way, Sera as heroin attends SMA 333 or triple three which is a famous school in Jakarta with high-class students' family background. It can be seen that code-switching is the type of code that is most widely used in the novel. The next discussion is the most type used in code-switching in this novel. According to the total that has been counted, intra-sentential switching is the most type used in the novel. Poplack (1980) states that code-switching is switching from one language variety to another at the clause, phrase, or word level within a single utterance. Intra-sentential switching takes place within the clause or sentence and considered to be the most complex form of switching. It means in one sentence it can be more than one language. The author managed to describe the high-class society by using a foreign language, namely English. The example from the novel, "Jadi gimana nih, cousin, mau di follow-up gak?" (p. 46).

According to the result that has been mentioned in the finding, there are three purposes that contributed to those occurrences. There are quoting somebody else, express solidarity, and express disapproval. These are 3 out 6 types stated by Holmes (2013). The result has answered all of the research question. It can be seen in the first, second, and the third findings. Overall, the complete result and finding of this research has proven that code-switching is the most code found in the novel, intra-sentential switching is the most type used in the novel, and there are three purposes used in the novel Me and You Versus the 
World. Code-switching is classified as the most found in the novel, which has 53 in total. Meanwhile, intra-sentential is classified as the most found in the novel, which has 27 in total. Hence, there are also some purposes that used in the novel Me and You Versus the World, namely, quoting somebody else, express solidarity, and express disapproval. The finding revealed the fact that s literary work is broad, there are many things that can be learned and discovered from a literary work. Starting from the language, word choice, social environment, and written style that characterizes a writer. Nonetheless, A novel with informal language styles cannot be used as a reference as the main medium of learning English. However, it can be used as a supporting medium to enrich knowledge about various literary works.

\section{CONCLUSION AND SUGGESTION}

This research is aimed to analyze the occurrence of code-switching and code-mixing in the novel Me and You Versus the World. After conducting and analysis the data it is revealed that code-switching is the most code found in the novel, intra-sentential switching is the most type used in the novel, and there are four possible purposes used in the novel Me and You Versus the World. They are quoting somebody else, express solidarity, switching for affective function, and express disapproval. It was proven by the total and the percentage. Moreover, this research also discovered that there were some possible purposes of switching and mixing a code in the novel. The possible purposes were proven by understanding the whole story and the six factors stated by Holmes (2013). The purposes had significant contribution to the story. Suggestion Based on the conclusion above, the researcher would like to suggest several points that connected to the result of this research. This study suggests that the reader must be understood for the book to be read. That means read the book that you really need. For example, if you want to learn English through a simple medium such as a novel, you have to really look for a novel that you can enjoy while providing the knowledge you need. The other researcher could conduct relevant research about code-switching and code-mixing in the novel and use this research as a reference.

\section{REFERENCES}

Adi, W. T. (2018). Code-switching in critical eleven novel. Methathesis. Methathesis, 39-57.

Ari, Donald at all. (2010). Introduction to Research in Education: Eighth Edition. United States of America: Wadsworth Cengange Learning.

Bowen G. A. (2009). Document analysis as a qualitative research method. Western Carolina University. Qualitative Research Journal, vol. 9, 27-40.

Holmes, J. (2013). An introduction to sociolinguistics: Fourth Edition. New York: Routledge

Jacqueline T. A. (2011). Code-switching among US latinos, the handbook of hispanic sociolinguistics, 530-552. United State of America: Blackwell.

Musyken, P. (2000). Bilingual speech: a typology of code-mixing. Retrieved from https://books.google.co.id/books/about/Bilingual_Speech.html?id=1JI7qrIKmokC \&printsec $=$ frontcover\&source $=\mathrm{kp} \_$read_button\&redir_esc $=\mathrm{y} \# \mathrm{v}=$ onepage\& $\& \mathrm{f}=\mathrm{fals}$ e\}

Ningsih, E. P. (2019). Code-switching and code-mixing in teching-learning process. Jurnal Pendidikan dan Pengajaran Khatulistiwa, 1-10

Poplack, S. (1980). Sometimes I'll start a sentence in Spanish y termino en Espanol: toward a typology of code-switching. Linguistics, 18(7/8), 581-618.

Prasad D. B. (2008). Content analysis: a method in social science research. New Delhi: Rawat.

Lestari, Susilawati, and Suhartono / JEEP Vol.3 No.1 (2022) 1-6. 
Wardhaugh, R. \& Fuller, J. (2015). An introduction to sociolinguistic: Seventh Edition. United Kingdom: Willey-Blackwell. 